\title{
Pendidikan dan Kesehatan: Urgensitas Edukasi Protokol Kesehatan untuk Masyarakat dalam Upaya Pencegahan Penyebaran Virus Covid-19 di Desa Cinta Rakyat
}

\author{
Ahmad Ali Habibi ${ }^{1 *}$, Vina Andini ${ }^{2}$, Tasya Azizah Anwar ${ }^{3}$, Abdurrahman $^{4}$ \\ ${ }^{1}$ Universitas Islam Negeri Sumatera Utara Medan, Indonesia \\ ${ }^{2}$ Universitas Islam Negeri Sumatera Utara Medan, Indonesia \\ ${ }^{3}$ Universitas Islam Negeri Sumatera Utara Medan, Indonesia \\ ${ }^{4}$ Universitas Islam Negeri Sumatera Utara Medan, Indonesia \\ *Corresponding Author. E-mail: ${ }^{1}$ achmadaly123@gmail.com
}

Receive: 13/01/2021

Accepted: 23/01/2021

Published: 01/3/2021

\begin{abstract}
Abstrak
Saat ini, Coronavirus Disease 2019 (Covid-19) menjadi salah satu permasalahan dunia dengan jumlah kasus yang selalu mengalami peningkatan. Pandemi Covid-19 yang terjadi jelas menimbulkan kekhawatiran masyarakat Indonesia dan perubahan perilaku kesehatan. Penelitian ini bertujuan untuk memberikan edukasi protokol kesehatan untuk masyarakat dalam pencegahan penyebaran Covid-19 di Desa Cinta Rakyat, Kecamatan Percut Sei Tuan, Kabupaten Deli Serdang. Adapun metode penelitian ini yaitu ceramah, diskusi dan observasi dengan sampel berjumlah 15 orang. Instrumen penelitian menggunakan lembar kuesioner. Hasil penelitian ini menunjukkan bahwa dari 15 orang yang menjadi responden merupakan masyarakat dengan kategori anak-anak, remaja dan dewasa mempunyai peningkatan pengetahuan mengenai protokol kesehatan. Edukasi protokol kesehatan untuk masyarakat dalam pencegahan penyebaran Covid-19 di Desa Cinta Rakyat sangatlah penting dan berpengaruh terhadap masyarakat sekitar.
\end{abstract}

Kata Kunci: Edukasi, Protokol Kesehatan, Covid-19

\section{Education and Health: The Urgency of Health Protocol Education for the Community in Efforts to Prevent the Spread of the Covid-19 Virus in Cinta Rakyat Village}

\begin{abstract}
Currently, Coronavirus Disease 2019 (Covid-19) is one of the world's problems with the number of cases always increasing. The Covid-19 pandemic that has occurred has clearly raised concerns for the Indonesian people and changes in health behavior. This study aims to provide education on health protocols for the community in preventing the spread of Covid-19 in Cinta Rakyat Village, Percut Sei Tuan District, Deli Serdang Regency. The research method is lecture, discussion and observation with a sample of 15 people. The research instrument used a questionnaire sheet. The results of this study indicate that of the 15 people who are respondents are people with categories of children, adolescents and adults who have increased knowledge about health protocols. Education on health protocols for the community in preventing the spread of Covid-19 in Cinta Rakyat Village is very important and has an effect on the surrounding community.
\end{abstract}

Keywords: Education, Health Protocol, Covid-19. 


\section{Pendahuluan}

Masyarakat dunia dihebohkan dengan adanya virus corona pada bulan Desember tahun 2019. Mulanya kejadian ini terjadi di Wuhan, Tiongkok (Yuliana, 2020: 187). Maraknya Covid-19 mengakibatkan berbagai hal yang baru, hampir seluruh kegiatan dilakukan dari rumah (Veta Lidya, dkk, 2021: 92)

Coronavirus Disease (Covid-19) adalah nama famili atau keluarga besar virus yang dapat menyebabkan penyakit pada manusia dan binatang. Pada manusia, umumnya virus ini menyebabkan infeksi saluran pernapasan dari ringan hingga berat, dengan penyakit yang tersering adalah batuk pilek biasa atau common cold (Nahla Shihab, 2020: 1) .

Tanda dan gejala umum infeksi Covid-19 antara lain gejala gangguan pernapasan akut seperti demam, batuk dan sesak napas. Pada kasus Covid-19 yang berat dapat menyebabkan pneumonia, sindrom pernapasan akut, gagal ginjal, dan bahkan kematian. Tanda-tanda dan gejala klinis yang dilaporkan pada sebagian besar kasus adalah demam, dengan beberapa kasus mengalami kesulitan bernapas, dan hasil rontgen menunjukkan infiltrat pneumonia luas di kedua paru.

Penelitian menunjukkan bahwa percikan batuk/ bersin (droplet) merupakan salah satu cara penularan Covid-19 dari manusia ke manusia (Kemenkes RI, 2020). Droplet di udara terhirup oleh manusia lain di dekatnya yang tidak terinfeksi Covid-19 melalui hidung ataupun mulut (Gennaro et al, 2020).

Di tahun 2021, kasus Covid-19 semakin meningkat. Satuan Tugas (Satgas) Penanganan Covid-19 mencatat jumlah pasien terpapar virus corona di Sumatera Utara hingga Januari 2021 mencapai 18.233 orang. Usai libur lebaran, pasien Covid-19 yang dirawat di RSUD Deli Serdang juga terus mengalami peningkatan dengan jumlah pasien sebanyak 98 orang. Deli Serdang termasuk salah satu daerah tertinggi di Sumatera Utara dengan terpaparnya positif Covid-19. Virus ini menyerang setiap orang tanpa memandang usia dan jenis kelamin (World Helth Organization, 2020).

Salah satu penyebab meningkatnya penyebaran Covid-19 adalah disebabkan oleh kurangnya pengetahuan dan disiplin masyarakat terhadap protokol kesehatan. Faktor kejenuhan, meningkatnya mobilitas dan munculnya varian baru Covid-19 juga termasuk penyebab penyebaran Covid-19.

Masyarakat yang belum menggunakan masker ketika di luar rumah masih seringkali ditemukan. Hal ini penting untuk menjadi perhatian guna menekan angka penularan positif Covid-19.

Salah satu cara preventif yaitu dengan memberikan edukasi kepada masyarakat melalui sosialisasi atau penyuluhan berbagai informasi mengenai Covid-19 dan protokol kesehatan. Sosialisasi tentang protokol kesehatan Covid-19 dapat memberikan pengetahuann dan menumbuhkan kesadaran bagi masyarakat untuk menerapkan protokol kesehatan sebagai upaya mencegah Covid19 (Suhadi, dkk, 2020).

Perilaku hidup bersih dan sehat adalah sekumpulan perilaku yang dipraktekkan atas dasar kesadaran hasil pembelajaran yang menjadikan seseorang atau keluarga dapat menolong dirinya sendiri di bidang dan kesehatan dalam mewujudkan kesehatan masyarakat (Deby Zulkarnain, dkk, 2020: 29). Salah satu bentuk perilaku hidup sehat adalah dengan menjaga kebersihan diri (Ashar, dkk, 2017). 
Jurnal Edumaspul, 5 (1), Year 2021 - 718

Pentingnya edukasi penerapan protokol kesehatan Covid-19 untuk masyarakat sangat ditekankan oleh Kepala Desa Cinta Rakyat, Bapak Suhendro, ST. Penanganan dan pencegahan Covid-19 merupakan salah satu hal yang utama. Dalam edukasi terkait Covid-19, masyarakat diajak untuk menerapkan $5 \mathrm{M}$, yaitu memakai masker ketika berada di luar rumah, menjaga jarak, mencuci tangan, menjauhi kerumunan dan mengurangi mobilitas. Hal ini diharapkan agar signifikan dapat mengurangi penyebaran Covid-19.

Oleh karena itu, penelitian ini bertujuan untuk menekankan pentingnya edukasi protokol kesehatan kepada masyarakat dalam pencegahan penyebaran Covid-19 di Desa Cinta Rakyat.

\section{Metode}

Sasaran penelitian ini adalah dengan mengambil sampel dari 15 orang yang merupakan masyarakat Desa Cinta Rakyat, Kecamatan Percut Sei Tuan, Kabupaten Deli Serdang. Metode penelitian yang digunakan adalah ceramah, diskusi dan observasi. Instrumen penelitian menggunakan lembar kuesioner. Penelitian dilakukan dengan memberikan edukasi protokol kesehatan kepada masyarakat dalam pencegahan penyebaran Covid-19.

\section{Hasil dan Pembahasan}

Responden yang diperoleh dalam penelitian ini berjumlah 15 orang. Responden adalah anak-anak berumur 810 tahun ( 7 orang), remaja berumur $15-18$ tahun (5 orang) dan dewasa berumur 2530 tahun (3 orang).

\begin{tabular}{|c|c|c|c|}
\hline No & RESPONDE & JUMLA & PERSEN \\
. & $\mathbf{N}$ & $\mathbf{H}$ & $(\%)$ \\
\hline
\end{tabular}

\begin{tabular}{|c|c|c|c|}
\hline 1. & $\begin{array}{c}\text { Anak-anak } \\
(8-10 \\
\text { tahun) }\end{array}$ & 7 orang & $46.7 \%$ \\
\hline 2. & $\begin{array}{c}\text { Remaja } \\
(15-18 \\
\text { tahun) }\end{array}$ & 5 orang & $33.3 \%$ \\
\hline 3. & $\begin{array}{c}\text { Dewasa } \\
\text { (25-30 } \\
\text { tahun) }\end{array}$ & 3 orang & $20 \%$ \\
\hline
\end{tabular}

Edukasi protokol kesehatan dilakukan oleh anggota KKN Kelompok 34 UINSU dengan memberikan ceramah kepada responden. Sebelum diberikan edukasi, responden diberikan lembar evaluasi singkat mengenai Covid-19. Hasilnya menunjukkan bahwa 10 dari 15 orang masih bingung terhadap pandemi Covid-19. Mereka menganggap bahwa Covid-19 hanyalah rekayasa (tidak ada) dan tidak mengerti protokol kesehatan. Hanya 5 orang saja yang dapat menjawab dengan benar dan tepat.

\section{A. Kegiatan Sosialisasi dan Penyuluhan Protokol Kesehatan}

Kegiatan sosialisasi dan penyuluhan yang dilaksanakan mengacu pada standar disiplin protokol kesehatan yang telah ditetapkan oleh Kementrian Kesehatan RI. Dalam kegiatan pemberian edukasi protokol kesehatan, anggota KKN Kelompok 34 melakukan ceramah sesuai penerapan $5 \mathrm{M}$, yaitu sebagai berikut.

1. Memakai masker

Semua orang yang sehat maupun sakit agar selalu menggunakan masker saat beraktivitas di luar. Gunakan masker bila batuk atau tutup mulut dengan lengan atas bagian dalam.

2. Menjaga jarak Jaga jarak dengan orang lain minimal 2 meter. 
3. Mencuci tangan

Rajinlah mencuci tangan menggunakan sabun dan air mengalir selama 40-60 detik atau menggunakan cairan antiseptik berbasis alkohol (handsanitizer) minimal 20-30 detik.

4. Menjauhi kerumunan

Menghindari kerumunan dan juga menghindari berkumpul di ruangan yang berventilasi kurang baik.

5. Mengurangi mobilitas

Bila tidak ada keperluan yang mendesak, tetaplah berada di rumah. Hindarilah berinteraksi dengan orang lain yang tidak diketahui status kesehatannya.

Melalui kegiatan edukasi ini, maka dapat meningkatkan pengetahuan dan kesadaran sasaran tentang Covid-19 (Tapung, dkk, 2020: 12). Kegiatan ini juga bermanfaat sehingga tetap produktif dan tetap sehat di saat pandemi Covid-19 yang masih melanda.

\section{B. Praktek Penerapan Protokol Kesehatan}

Tindakan pencegahan merupakan kunci penerapan di pelayanan kesehatan dan masyarakat. Langkah pencegahan di masyarakat adalah dengan menjaga kebersihan tangan menggunakan hand sanitizer jika tangan tidak terlihat kotor. Cuci tangan dengan sabun jika tangan terlihat kotor (Anggun Wulandari, dkk, 2020: 42).

Anggota KKN Kelompok 34 UINSU mempraktekkan mengenai cara mencuci tangan yang benar serta menekankan pentingnya melakukan aktivitas fisik (olahraga ringan) dan konsumsi makanan yang sehat.

Tahap selanjutnya, pembagian masker secara gratis dilakukan kepada masyarakat. Pembagian masker diharapkan dapat mendorong masyarakat untuk menerapkan kebiasaan menggunakan masker selama berada di luar rumah.
Kegiatan ini bertujuan sebagai sarana edukasi bagi masyarakat agar rajin menggunakan masker untuk mencegah penularan Covid-19. Pada saat pembagian masker, masyarakat juga diberikan contoh praktek secara langsung terkait penggunaan masker yang baik dan benar.

Berikut adalah hasil peningkatan pengetahuan responden sebelum dan sesudah diberikan edukasi protokol kesehatan.

\begin{tabular}{|c|c|c|c|}
\hline Usia & $5 M$ & $\begin{array}{l}\text { Sebelu } \\
\text { m }\end{array}$ & $\begin{array}{c}\text { Sesuda } \\
h\end{array}$ \\
\hline \multirow{5}{*}{$\begin{array}{l}\text { Anak- } \\
\text { anak } \\
\text { (8-10 } \\
\text { tahun) }\end{array}$} & $\begin{array}{l}\text { Memakai } \\
\text { Masker }\end{array}$ & B & $A$ \\
\hline & $\begin{array}{c}\text { Menjaga } \\
\text { Jarak }\end{array}$ & $C$ & B \\
\hline & $\begin{array}{l}\text { Mencuci } \\
\text { Tangan }\end{array}$ & $C$ & $A$ \\
\hline & $\begin{array}{c}\text { Menjauhi } \\
\text { Kerumuna } \\
\mathrm{n}\end{array}$ & C & B \\
\hline & $\begin{array}{c}\text { Menguran } \\
\text { gi } \\
\text { Mobilitas }\end{array}$ & C & B \\
\hline \multirow{5}{*}{$\begin{array}{c}\text { Remaja } \\
\text { (15-18 } \\
\text { tahun) }\end{array}$} & $\begin{array}{l}\text { Memakai } \\
\text { Masker }\end{array}$ & B & $A$ \\
\hline & $\begin{array}{l}\text { Menjaga } \\
\text { Jarak }\end{array}$ & $C$ & B \\
\hline & $\begin{array}{c}\text { Mencuci } \\
\text { Tangan }\end{array}$ & $B$ & B \\
\hline & $\begin{array}{c}\text { Menjauhi } \\
\text { Kerumuna } \\
\mathrm{n}\end{array}$ & C & $A$ \\
\hline & $\begin{array}{c}\text { Menguran } \\
\text { gi } \\
\text { Mobilitas }\end{array}$ & C & $A$ \\
\hline \multirow{4}{*}{$\begin{array}{c}\text { Dewasa } \\
\text { (25-30 } \\
\text { tahun) }\end{array}$} & $\begin{array}{c}\text { Memakai } \\
\text { Masker }\end{array}$ & $A$ & $A$ \\
\hline & $\begin{array}{c}\text { Menjaga } \\
\text { Jarak }\end{array}$ & B & $A$ \\
\hline & $\begin{array}{c}\text { Mencuci } \\
\text { Tangan }\end{array}$ & $B$ & $A$ \\
\hline & $\begin{array}{c}\text { Menjauhi } \\
\text { Kerumuna } \\
\mathrm{n}\end{array}$ & B & $A$ \\
\hline
\end{tabular}




\begin{tabular}{|c|c|c|c|}
\hline & $\begin{array}{c}\text { Menguran } \\
\text { gi } \\
\text { Mobilitas }\end{array}$ & A & A \\
\hline
\end{tabular}

Keterangan pengetahuan terkait 5M
A : Sangat Baik
B : Baik
C : Cukup Baik

\section{PEMBAHASAN}

Penelitian ini menunjukkan bahwa setelah diberikan edukasi protokol kesehatan, maka terjadi peningkatan pengetahuan responden tentang Covid-19 dan protokol kesehatan.

Sebelum edukasi, hanya 5 dari 15 responden yang memahami protokol kesehatan dengan persentase pengetahuan sekitar 33.3\%. Sesudah edukasi, 12 dari 15 responden telah memahami dan mampu mempraktekkan protokol kesehatan dengan persentase pengetahuan sekitar $80 \%$.

Hal ini dibuktikan ketika para responden ditanya oleh narasumber terkait topik edukasi. Mereka juga sudah dapat mempraktekkan cuci tangan yang benar, menggunakan masker yang tepat dan mematuhi aturan protokol kesehatan lainnya. Kegiatan ini penting dilakukan oleh Anggota KKN Kelompok 34 UINSU untuk menambah pengetahuan masyarakat terkait pentingnya penerapan protokol kesehatan dan pengaruhnya untuk masyarakat dalam pencegahan penyebaran Covid-19. Edukasi melalui penyuluhan merupakan metode yang efektif dalam upaya meningkatkan pengetahuan pada suatu kelompok (Suwarni, dkk, 2020: 249).

Penyakit ini harus diwaspadai karena penularan yang relatif cepat, memiliki tingkat mortalitas yang tidak dapat diabaikan dan belum adanya terapi definitif. Masih banyak kesenjangan pengetahuan yang terjadi terkait penyakit ini berdasarkan karakteristik individu yang telah diteliti, sehingga diperlukan upaya penanggulangan dan studi-studi lebih lanjut (Susilo, dkk, 2020: 45).

Dengan adanya edukasi ini, masyarakat dan kalangan muda/ remaja kini harus lebih berperan aktif dalam membantu pemerintah dalam penvegahan penyebaran Covid-19. Masyarakat memiliki peran penting dalam mendukung penyelenggaraan kesejahteraan sosial.

\section{Simpulan}

Edukasi protokol kesehatan yang dilakukan oleh Anggota KKN Kelompok 34 UINSU kepada masyarakat dalam pencegahan penyebaran Covid-19 di Desa Cinta Rakyat sangat penting dan berpengaruh terhadap masyarakat sekitar. Berdasarkan hasil edukasi terhadap responden, dapat diketahui bahwa baik anak-anak, remaja dan dewasa sudah mulai menunjukkan peningkatan pengetahuan mereka terkait protokol kesehatan. Hal ini dibuktikan ketika masyarakat mengurangi aktivitas di luar rumah, menggunakan masker ketika di luar, dan menjaga jarak saat bertemu orang lain.

\section{UCAPAN TERIMA KASIH}

Tim Kuliah Kerja Nyata (KKN) Kelompok 34 mengucapkan terima kasih yang tak terhingga kepada LP2M Universitas Islam Negeri Sumatera Utara, Kepala Desa dan Kepala Dusun Desa Cinta Rakyat, serta seluruh pihak yang telah berpartisipasi pada kegiatan ini.

\section{Daftar Pustaka}

[1] Anggun, et.al. (2020). Hubungan Karakteristik Individu dengan Pengetahuan tentang Pencegahan 
Coronavirus Disease 2019 pada Masyarakat di Kalimantan Selatan. Jurnal Kesehatan Masyarakat.

[2] Ashar, et.al. (2017). Hubungan Pengetahuan Tentang Cuci Tangan dengan Sikap Cuci Tangan pada Anak SDN 2 Rogodono Kecamatan Buayan Kebumen. Jurnal Stikes Muhammadiyah Gombong.

[3] Deby, et.al. (2020). Edukasi Penerapan Protokol Kesehatan Penyelenggaraan Kegiatan Baca Tulis Al-Quran pada Masa Pandemi Covid-19 TPQ Masjid Awalumu'minin Gamping. Jurnal Pengabdian Masyarakat, 2 (2).

[4] Direktorat Jenderal Pencegahan dan Pengendalian Penyakit (P2P). Pedoman Pencegahan dan Pengendalian Coronavirus Dissease (Covid-19). Jakarta: Kementrian Kesehatan RI.

[5] Gennaro, F. Pizzol D., et.al. (2020). Coronavirus Disease (Covid-19) Current Status and Future Perspectives: A Narrative Review. International Journal of Environmental Research and Public Health.

[6] Kementrian Kesehatan RI. (2020). Pedoman Pencegahan dan Pengendalian Coronavirus Disease (Covid-19). Direktorat Jenderal Pencegahan dan Pengendalian Penyakit.

[7] Peraturan Menteri Kesehatan (Permenkes) Nomor 9 Tahun 2020 tentang Pedoman Pembatasan Sosial Berskala Besar dalam Rangka
Percepatan Penanganan Corona Virus Disease 2019 (Covid-19).

[8] Shihab, Nahla. (2020). Covid-19 (Kupasan Ringkas yang Perlu Anda Ketahui). Tangerang Selatan: Lentera Hati.

[9] Suhadi, et.al. (2020). Promosi Kesehatan Berbasis Daring Mengenai Perilaku Pencegahan Covid-19 Bagi Masyarakat Kota Kendari. Jurnal Anoa, 1 (3).

[10] Susilo, et.al. (2020). Coronavirus Disease 2019. Jurnal Penyakit Dalam Indonesia, 7 (1).

[11] Suwarni, et.al. (2020). Pendampingan dan Peningkatan Kapasitas Kader Relawan Stunting di Wilayah Kerja Puskesmas Rasau Jaya Kalimantan Barat. Journal Social economic of Agriculture.

[12] Tapung, et.al. (2020). Bantuan Sosial dan Pendidikan Kesehatan Bagi Masyarakat Pesisir yang Terdampak Sosial Ekonomi selama Covid-19 di Manggarai. Transformasi Jurnal Kesehatan Masyarakat.

[13] Veta, et.al. (2021). Pengaruh Disiplin Protokol Kesehatan Terhadap Pencegahan Penularan Virus Covid-19. Jurnal Abdimas, 2 (2).

[14] Yuliana. (2020). Coronavirus Diseases (Covid-19) Current Status and Future Perspectives: A Narrative Review. International Journal of Environmental Research and Public Health, 17 (8).

[15] World Health Organization. (2020). Novel Coronavirus. 